Journal of Tropical Ecology

www.cambridge.org/tro

\section{Research Article}

Cite this article: Einzmann HJR, Zotz G, and Tay JYL (2022) What happens to epiphytic bromeliads in a windy spot? Journal of Tropical Ecology 38, 158-163. https://doi.org/10.1017/ S0266467422000037

Received: 30 August 2021

Revised: 12 November 2021

Accepted: 2 January 2022

First published online: 21 February 2022

\section{Keywords:}

attachment; Panama; vascular epiphytes; video observation; wind

\section{Author for correspondence:}

Helena Julia Regina Einzmann, Email: helena.einzmann@uol.de

\title{
What happens to epiphytic bromeliads in a windy spot?
}

Helena Julia Regina Einzmann ${ }^{1}(\mathbb{0})$, Gerhard Zotz ${ }^{1,2}$ (i) and Jessica Ying Ling Tay $^{1}$ (1)

${ }^{1}$ Functional Ecology of Plants, Institute of Biology and Environmental Sciences, Carl von Ossietzky University, Oldenburg, Germany and ${ }^{2}$ Smithsonian Tropical Research Institute, Panama, Republic of Panama

\begin{abstract}
Several studies of hurricane damage on epiphyte communities implied that epiphytes might be in danger of being blown off their host when subjected to strong wind. There is very limited knowledge about the mechanical impact that wind may have on epiphytes. Using a wind-triggered camera set-up, we observed how epiphytic tank bromeliads are affected by wind. Despite offering a relatively large area of 'attack' to the airflow, bromeliads moved relatively little themselves. Rather than being directly moved by wind, the bromeliads in the upper crown of tall trees moved with the sway of the branches. Only when the substrate did not move, bromeliads with long broad leaves showed considerable disturbance due to wind. Our observations underline the complexity of the system and emphasise that our current understanding of the mechanical aspects of the epiphyte-host system is still very limited.
\end{abstract}

\section{Resumen}

Varios estudios sobre los daños causados por los huracanes en las comunidades de epífitas indican que éstas pueden correr el riesgo de desprenderse de su árbol hospedero cuando se ven sometidas a fuertes vientos. Los conocimientos sobre el impacto mecánico que el viento puede tener en las epífitas son muy limitados. Utilizando una cámara activada por el viento, observamos cómo las bromelias-tanque epífitas se ven afectadas por el viento. A pesar de ofrecer un área de "ataque" relativamente grande al flujo de aire, las bromelias se movían relativamente poco por sí mismas. En vez de ser movidas directamente por el viento, las bromelias situadas en la copa de los árboles altos se movían con el vaivén de las ramas. Sólo cuando el sustrato no se movía, las bromelias con hojas largas y anchas mostraban una perturbación considerable debida al viento. Nuestras observaciones subrayan la complejidad del sistema, tanto como la limitación de nuestra comprensión de los aspectos mecánicos del sistema epífito-huésped.
(C) The Author(s), 2022. Published by Cambridge University Press. This is an Open Access article, distributed under the terms of the Creative Commons Attribution licence (http:// creativecommons.org/licenses/by/4.0/), which permits unrestricted re-use, distribution and reproduction, provided the original article is properly cited.

\section{Introduction}

Epiphytes are an important part of many tropical forests. Growing on other plants, mainly trees, without tapping into the water and nutrient flow of the host they are not parasites (Zotz 2016). However, a large number of epiphytes in a tree may lead to structural failure of branches (Strong 1977). Substrate stability is obviously important for structurally dependent epiphytes and structural failure accounts for a large proportion of deaths (Hietz 1997, Hietz et al. 2002, Sarmento Cabral et al. 2015, Schmit-Neuerburg 2002, Zotz 1998, Zotz et al. 2005). Under extreme conditions, that is, hurricanes (category 1 with wind speeds from $33 \mathrm{~m} \mathrm{~s}^{-1}$ ), forest canopies suffer severe damage (e.g., Hirsh \& Marler 2002, Lugo et al. 1983, Vozmishcheva et al. 2019). The mechanical effect of wind on epiphytes themselves is hardly studied (but see Tay et al. 2021), although the possibility of epiphytes being dislodged by wind is repeatedly mentioned in the literature, albeit without quantitative data (e.g., Francisco-Ventura et al. 2018, Lowman \& Linneroth 1995, Pett-Ridge \& Silver 2002, Rodríguez-Robles et al. 1990). Typically, epiphytes growing in a closed forest do not experience very strong wind, although wind speed within a forest is clearly site dependent. The wind speed measured within tropical forests in the studies of Hales (1949, lowland Panama), Baynton et al. (1965, lowland Colombia), Aoki et al. (1975, lowland Malaysia), and Lawton (1982, lower montane forest Costa Rica) ranged between $<1$ to ca. $50 \%$ of the mean wind speed measured above the forest, where wind speeds reached $3.5-11 \mathrm{~m} \mathrm{~s}^{-1}$. In more open forests, the wind speed gradient is less steep as wind enters easier into lower strata as compared to forests with denser vegetation. A mountain ridge forest studied by Lawton (1982) was very exposed and experienced ca. two to three times higher wind speeds than the mentioned lowland forests. Wind flow in and directly above forests is highly turbulent; therefore, forces acting on the plants in the forest are not simply a function of the mean wind speed. Forces exerted by gusts, that is, a sudden and brief (3-20 s) increase in wind speed (American Meteorological Society 2012), can be 10 times greater than the forces from mean wind speed measured (Moore et al. 2018). At least in the topmost layers of the 
canopy violent wind gusts can be expected. Within tree crowns, turbulent wind may thus play a detrimental role that could possibly cause substrate or attachment failure of epiphytes. Since wind conditions in the upper tree crows are arguably most critical to epiphytes, we will focus on this aspect.

Due to increased human pressure in countries in the tropics, the habitat still available to epiphytes is increasingly of a secondary and fragmented type, and the wind dynamics change in fragmented landscapes. The higher relative wind speeds found within more open forests (Hales 1949, Latimer 1950) already hint at this aspect. Epiphytes on isolated trees in, for example, pastures have hardly any protection from wind due to the lack of surrounding vegetation and may also suffer the most in a storm (Lowman \& Linneroth 1995). In still forested areas, ongoing fragmentation creates more abrupt edges resulting in wind entering the forest more easily (Laurance \& Curran 2008) leading to an increase in tree mortality and wood-debris production close to the fragment edge (Laurance 2006). Although mean wind loads are larger at the forest edges, the ratio of maximum load to mean load on a tree increases with distance from the edge (Moore et al. 2018). Thus, trees and consequently epiphytes, inside the forest, may experience only low mean wind speeds in general but have to cope with comparatively stronger gust loads. With this general background information, we investigated what actually happens to epiphytes in a strong wind flow. The influence of wind on plants has been investigated in a range of plants from small terrestrial seedlings (e.g., Ennos 1991) to large trees (e.g., Hale et al. 2012), but until recently never in epiphytes (but see Tay et al. 2021). Wind can cause considerable drag on the overall plant, leading to temporal form changes by reconfiguration of the leaves (Harder et al. 2004, Vogel 1989). Reconfiguration is not always possible, however, and leaves can be damaged due to fluttering in the wind (Skutch 1930, Vogel 1989). Small epiphytes and those that grow close to their substrate, for example, creeping ferns, expose very little frontal area to wind and should experience little force (Tremblay 2008). In contrast, erect growing bromeliads, with their densely clustered leaves, expose a large frontal area to wind and are limited in their ability to reduce the exposed area, at least around their base (Tay et al. 2021). Therefore, in this study we focused on how epiphytic tank bromeliads are affected by strong wind. We expected to observe that they are considerably impacted by wind, that is, showing flapping leaves, bent foliage, and similar distortions.

\section{Material and methods}

To observe how tank bromeliads behave during the onset of wind in their natural habitat, we used a custom-built camera set-up that would start taking a minimum 15 -second video triggered by a preset wind speed. This triggering speed was adjusted so that neither too many nor too few videos would be initiated; therefore, it differed between trees. The set-up used a cup-anemometer on top of an acrylic glass box that held an action camera connected to a rechargeable battery and an electronic unit controlled with an Arduino board (Figure 1). Whenever possible this set-up was installed on the same branches that hosted the focal bromeliads so that the movement of the substrate would be the same for both camera and epiphyte. Next to the camera set-up, within max. $1 \mathrm{~m}$ distance, an anemometer (Davis ${ }^{\circledR}$ Wind Speed and Direction Smart Sensor, Bourne - MA, USA) with logger (Onset HOBO Microstation, Bourne - MA, USA) was installed and it recorded

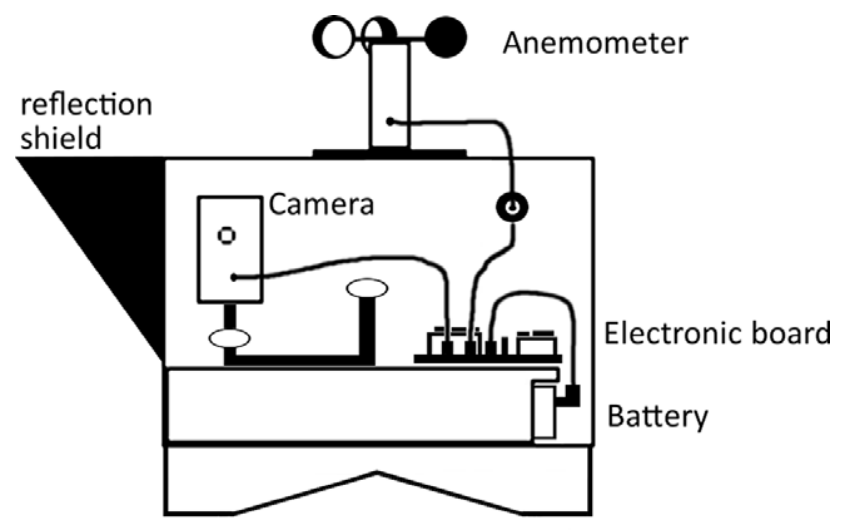

Figure 1. Custom-built camera set-up with an anemometer that triggers the camera in the acrylic glass housing to take a short video sequence when the trigger wind speed is reached. A second anemometer with a data logger was installed within $1 \mathrm{~m}$ of the camera set-up.

the wind speed in the tree close to the observed epiphytes. Wind speed was recorded as mean over 1 minute and as the highest 3-second interval during this logging interval.

The cameras were set up in the Fortuna Forest Reserve (Dalling \& Turner 2021), Panama, an area that experiences frequent and strong wind impact. The Fortuna Forest Reserve covers 19,500 ha with an elevation range of 700-2,000 $\mathrm{m}$. It encompasses perhumid to superhumid aseasonal and seasonal forests over a complex geology. The present study was conducted at the elevation of ca. 1,050-1,150 m a.s.l. with mean annual rainfall of ca. 5,000-6,000 $\mathrm{mm}$ and mean temperature of $19-20^{\circ} \mathrm{C}$ (Prada et al. 2017). In 2019 and 2020, wind was strongest in the months of January through March with mean wind speeds $>2.8 \mathrm{~m} \mathrm{~s}^{-1}$, whereas in the rest of the year the mean was $<2.5 \mathrm{~m} \mathrm{~s}^{-1}$ (Paton 2021). The cameras were mounted for one week from 26 March to 01 April 2019. Eight trees were chosen. Three of them grew in a clearing ( $\left.8^{\circ} 43^{\prime} 20.2^{\prime \prime} \mathrm{W} 82^{\circ} 14^{\prime} 14.1^{\prime \prime}\right)$ between the forest edge and the road on a hillside, two grew in the forest $\left(\mathrm{N} 8^{\circ} 45^{\prime}\right.$ $\left.26.7^{\prime \prime} \mathrm{W} 82^{\circ} 13^{\prime} 01.8^{\prime \prime}\right)$, and three grew at the borders of very small patches of forest or bushy area along the road close to a mountain pass (N8 $\left.{ }^{\circ} 41^{\prime} 31.1^{\prime \prime} \mathrm{W} 82^{\circ} 13^{\prime} 45.8^{\prime \prime}\right)$ that experiences strong wind almost constantly (Figure 2). One of the two forest trees, growing further up the slope, had a more exposed crown emerging from the forest canopy, whereas the other one had no emergent crown and grew further down the slope. In all trees, except two bush-like trees along the road, the cameras and anemometer were installed in what would correspond to Johansson zone 3, although none of the trees closely resembled Johansson's idealised tree form (Johansson 1974). The aim was not to systematically document differences between habitats but to observe epiphytes in relatively strong wind in diverse situations in a montane forest. Three cameras were available at the beginning, so that observations were possible in a maximum of three trees at any time. Due to logistical limitations in regard to climbing and availability of measuring devices, the periods in which data could be collected in the different trees varied considerably from ca. 8 hours to almost 2 days (Figure 3). The observed bromeliads were tank-forming species and ranged in their growth habit from a rather compact form, with erect leaves that did not tilt at their tips, to others with fewer but longer and tilting leaves. It was not relevant for this study to identify individual species, since our focus lies on the mechanical interaction for which only the wind obstructing body on the branch is relevant, not the species as such. 


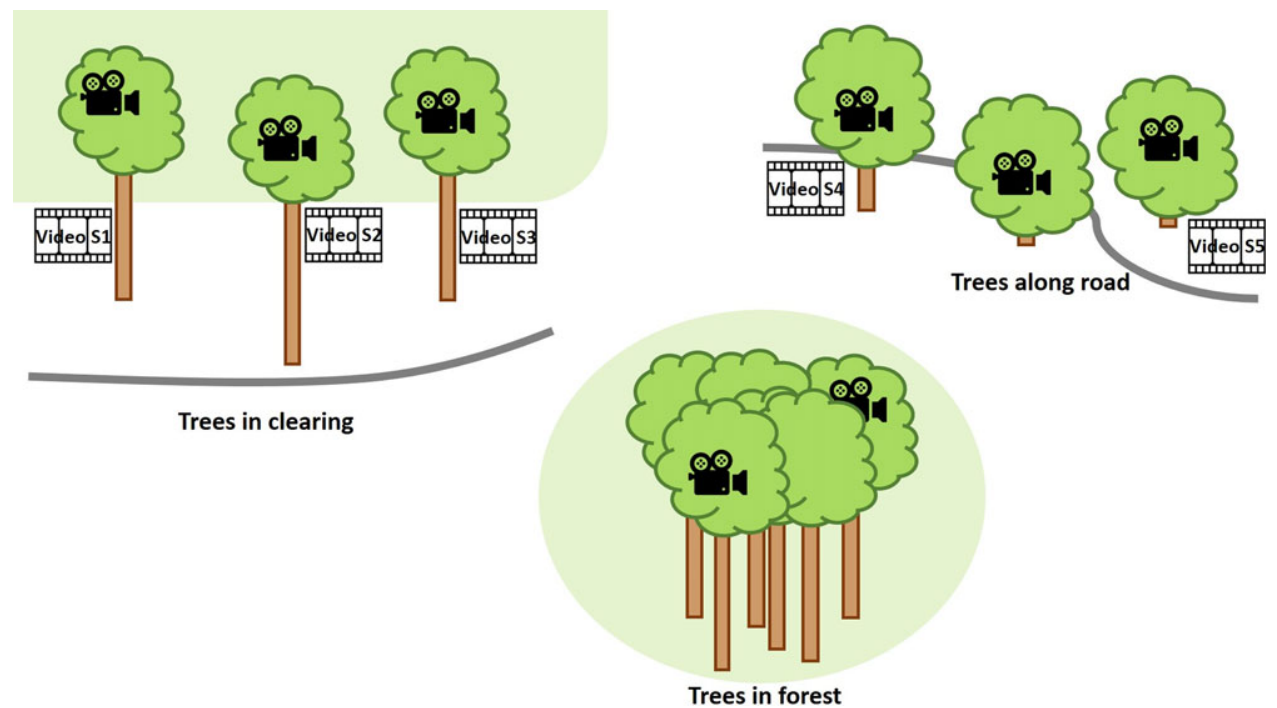

Figure 2. Schematic overview of study sites and trees where videos provided in the supplementary material were recorded.

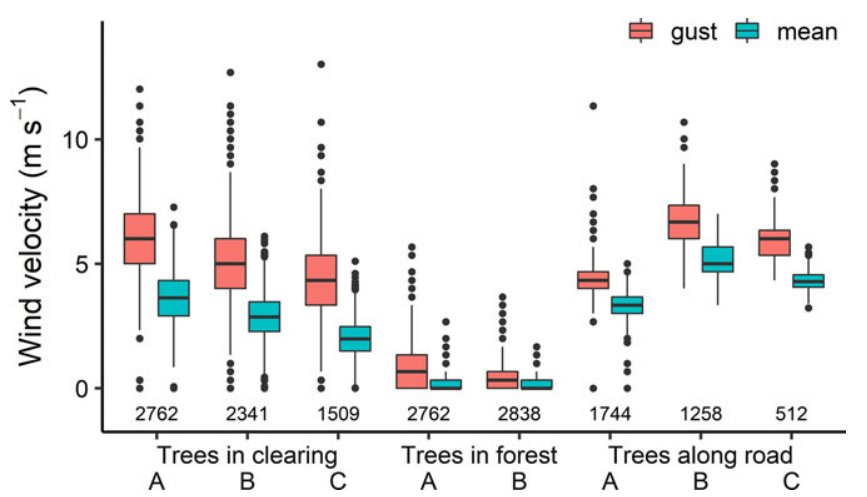

Figure 3. Wind speed in trees in a clearing between the road and the forest, trees in a forest, and trees along a road close to a mountain pass. Gusts represent the 3-second maximum speed measured over a time interval of 1 minute, and mean wind speed are 1-minute averages. Numbers under boxplots indicate $n$ per boxplot, that is, total time of measurement in minutes. Boxes depict the inter-quartile range (IQR) between the first and third quartiles. The lower and upper whiskers extend from the hinges of the first and third quartiles to the smallest and largest value no further than $1.5^{\star} \mathrm{IQR}$ from the hinge, respectively. Data points beyond the whiskers are plotted individually.

\section{Results and discussion}

The mean wind speeds measured ranged from $2.0 \pm 0.8$ to $3.6 \pm 1.1 \mathrm{~m} \mathrm{~s}^{-1}$ (data are means \pm standard deviations, $\mathrm{n}$ is given in Figure 3) in the trees in the clearing, $0.1 \pm 0.3$ to $0.3 \pm 0.4 \mathrm{~m} \mathrm{~s}^{-1}$ in the forest trees, and $3.4 \pm 0.5$ to $5.0 \pm 0.7 \mathrm{~m} \mathrm{~s}^{-1}$ in the trees along the road at the mountain pass. Maximum gust velocities ranged from 12.0 to $13.0 \mathrm{~m} \mathrm{~s}^{-1}$ in the trees in the clearing, 3.7 to $5.7 \mathrm{~m} \mathrm{~s}^{-1}$ in the forest trees, and 9.0 to $11.4 \mathrm{~m} \mathrm{~s}^{-1}$ in the trees along the road at the mountain pass (Figure 3 ). We compared the wind speed measured in the trees growing in the clearing to the wind speed measured by the anemometer installed in this clearing by the Physical Monitoring Program of the Smithsonian Tropical Research Institute (Paton 2021). The average and maximum wind speeds in the crown of tree A during the three days of measurements were very similar to the daily averages and maximums measured in the open clearing (Paton 2021). Naturally, the difference depended greatly on the openness of the tree crown. In tree A, in which the setup was installed in a very exposed position, the difference to the mean wind speed in the clearing was only $0.1 \mathrm{~m} \mathrm{~s}^{-1}$, whereas in the other two trees differences ranged from 0.7 to $1.7 \mathrm{~m} \mathrm{~s}^{-1}$.

The crown of tall trees tends to sway in the wind. The relatively slender trees in the study area were very flexible, and the swaying was pronounced. However, the bromeliads themselves growing on these slender hosts were moved very little by the wind (Video S1). The strongest movement we observed was limited vibration of the leaf tips or flapping of a damaged outer leaf (Video S2 and S3). We focused on bromeliads because of their compact habit that exposes a large area to the wind. Long and thin stalks of, for example, Orchidaceae or slender branches of Ericaceae tended to flap a lot more in the wind (Video S1). In smaller-statured stout trees, movement of the main branches was much more limited. Bromeliads growing in these trees showed some flapping of the leaves if these were long and broad. Bromeliads with a compact structure did not show any movement (Video S4). In small-statured slender trees and bush-like trees, the bromeliads themselves moved again very little; however, their substrate moved a lot in the wind (Video S5).

In general, a rigid object that is exposed to wind flow experiences a considerable force on its body that increases quadratically with increasing wind speed (Reynolds numbers from $1 \times 10^{3}-$ $3 \times 10^{5}$; Schlichting \& Gersten 2017). But plants are typically able to bend when exposed to wind, thus reducing the total frontal area exposed to wind which in turn decreases the drag force acting on them (de Langre et al. 2012, Harder et al. 2006, Vogel 1984). The videos stress the complexity of the epiphyte-host system by showing that apparently a lot of the force exerted on the epiphytes by wind is mitigated by the movement of the substrate, that is, swaying of the branches or tree crowns. In fact, looking at the entire body of an epiphyte, it seemed that the relatively stiff body of the bromeliads was much less disturbed by wind than that of the more flexible, long-stalked Orchidaceae or Ericaceae that flapped considerably in the wind. However, from our observations we cannot tell if this flapping caused damage to the stalks, but at least no obvious damage was sustained by the movement. Wind tunnel experiments with long- and broadleaved bromeliads showed that excessive flapping of the leaves at high wind speeds (30-50 $\mathrm{m} \mathrm{s}^{-1}$, unpubl. data) leads to tearing and consequently considerable damage. Such high wind speeds were not observed in the present study, and only minor damage was observed in a study that 
tested bromeliads in a wind tunnel with wind speeds up to $22 \mathrm{~m} \mathrm{~s}^{-1}$ (Tay et al. 2021). The maximum wind speed observed during the week of observations was $13 \mathrm{~m} \mathrm{~s}^{-1}$ in the tree crowns of the clearing. The maximum wind speed measured in the clearing since the start of the wind data collection in 2019 was ca. $19 \mathrm{~m} \mathrm{~s}^{-1}$ (Paton 2021). Therefore, it seems unlikely that wind would damage, let alone detach, epiphytes under normal circumstances even in the exposed sites in Fortuna. In fact, our observations imply that it is highly unlikely that wind alone could dislodge epiphytes, at least at the wind speeds measured here.

During a severe storm like a hurricane, the system is obviously exposed to an entirely different level of forces. It is unclear, however, if the bottleneck is the attachment failure of the epiphytes or substrate failure. Therefore, the implication that epiphytes are blown off by wind (Lowman \& Linneroth 1995, Matelson et al. 1993, Rodríguez-Robles et al. 1990) may be premature. One also has to consider that the fall of vascular epiphytes is most likely not determined by a single factor, but by the interaction of several, such as wind, precipitation, unstable substrate, arboreal animals, or even the weight of the epiphyte itself (e.g., Francisco-Ventura et al. 2018, Hietz 1997, Sarmento Cabral et al. 2015).

The force acting on a body in a flow environment depends on the frontal area, among other variables. When epiphytes grow on a tree in large numbers, they will increase the overall frontal area that this tree exposes to the wind. Additionally, they increase the load of the branch hosting them, especially when epiphytes are saturated with water after rainfalls. In a study of the role of epiphytes in rainfall interception from the same study region, the water-holding capacity of the epiphytic matter was estimated to be $>25,000 \mathrm{~L}$ $\mathrm{ha}^{-1}$ (Gómez González et al. 2021). Looking at the whole epiphyte-host system, how much impact does the increased frontal area and epiphyte load have on the swaying of the trees? The movement of the crown of tall trees is probably mainly initiated by the collective area the leaves expose to the wind (Duryea et al. 2007, Nilsson et al. 2004). Whether epiphytes significantly increase the exposed surface in comparison to the area of tree foliage remains unclear. On average, vascular epiphyte biomass is equivalent to about $10 \%$ of the green biomass of the co-occurring trees in montane forests (Zotz 2016). If most of these $10 \%$ would simultaneously increase the frontal area of their hosts, epiphytes could have a considerable impact on host tree dynamics in wind flow. However, this number is very vague, and there are cases where the green biomass of the epiphytes even exceeds that of the tree foliage (Díaz et al. 2010). Therefore, it is also highly speculative how much of that biomass contributes significantly to the increase of the exposed surface of the host and how much effect the additional weight has. Most likely, the area of tree foliage has such a large impact because it is found in the outermost crown (Video S3) where the exposed area will cause the greatest torque. The bulk of epiphytes, in comparison, grows on large branches and those that grow close to the trunk and in the inner crown may have comparatively little impact on the torque acting on the tree. Extreme swaying may cause some damage to the tree, but gentle swaying as a regular stimulus should already cause some adjustment of the wood body (Niez et al. 2020, Telewski \& Pruyn 1998). In contrast, another recent study found that extreme wind events had a greater impact on thigmomorphogenic response in European beech than did daily wind speed peaks (Bonnesoeur et al. 2016). If epiphytes increase the drag force acting on their host during a storm considerably, this could be detrimental to their host and consequently also to them. Several authors have used the term 'structural parasite' for the bromeliad species Tillandsia recurvata growing on different hosts (Flores-Palacios 2016, Montaña et al. 1997, Perez-Noyola et al. 2020). In these studies, the potential negative effect was caused by the presence of the bromeliad alone, without any further influence of wind. In our scenario, the negative effect could be due to the general presence of many epiphytes on a host in combination with the external wind factor. However, to our knowledge, there are no data on any of the mechanical aspects, for example, how much of the increase in frontal area of the host is caused by epiphytes, how this affects the short- or long-term stability of the host, or how host stability is affected by the additional weight in a static or dynamic situation.

\section{Conclusion}

In conclusion, stiff-bodied epiphytes such as bromeliads seem to receive less direct force through wind when growing on a relatively flexible substrate as compared to growing on a fixed substrate. This makes it less likely for them to be blown of individually during strong wind events and it implies that wind alone is unlikely to dislodge them. This is also supported by the study of Sarmento Cabral et al. (2015), which showed that the majority of epiphytes on the floor were found attached to branches and twigs. How much epiphytes contribute or enhance the swaying of their host trees leading to possible branch breakage during extreme gusts remains an open question. If epiphytes increase the likelihood that their host trees are damaged during wind events substantially, another facet would be added to the nature of the interaction described as 'structural parasitism'. To identify if epiphyte loads contribute to swaying and breakage of the host tree during high winds, a manipulation experiment might be necessary, in which one strips trees of their load and adds loads to other trees. Another approach could be to model flow dynamics using a modelled empty tree (Hackenberg et al. 2014, Hackenberg et al. 2015, Raumonen et al. 2013) and then systematically increase epiphyte load.

Supplementary material. To view supplementary material for this article, please visit https://doi.org/10.1017/S0266467422000037

Acknowledgements. We thank Calixto Rodríguez for his untiring assistance during the fieldwork and translation of the abstract into Spanish and Thomas Madena and Janek Willms, Carl von Ossietzky University Oldenburg, for the construction of the 'wind-cameras'. We also acknowledge the assistance of STRI personnel, Enel Green Power Panamá and the Republic of Panamá for making their natural resources available for research (Research Permit No. $\mathrm{SE} / \mathrm{P}-1-19)$.

Financial support. This work was supported by the DFG (grant no. EI 1092/1-1).

Competing interests declaration. The corresponding author confirms on behalf of all authors that there have been no involvements that might raise the question of bias in the work reported or in the conclusions, implications, or opinions stated.

Authors' contribution statement. Conceptualisation: (Helena Einzmann, Gerhard Zotz); data curation, methodology, formal analysis, and visualisation: (Helena Einzmann); investigation: (Helena Einzmann, Jessica Tay); writing original draft preparation: (Helena Einzmann); writing - review and editing: (Helena Einzmann, Gerhard Zotz, Jessica Tay); funding acquisition: (Helena Einzmann); supervision: (Gerhard Zotz).

\section{References}

American Meteorological Society (2012) Glossary of meteorology - gust. Web page. Available at https://glossary.ametsoc.org/wiki/Gust (accessed 13 July 2021). 
Aoki M, Yabuki K and Koyama H (1975) Micrometeorology and assessment of primary production of a tropical rain forest in West Malaysia. Journal of Agricultural Meteorology 31, 115-124.

Baynton HW, Biggs WG, Hamilton HL, Sherr PE and Worth JJB (1965) Wind structure in and above a tropical forest. Journal of Applied Meteorology and Climatology 4, 670-675.

Bonnesoeur V, Constant T, Moulia B and Fournier M (2016) Forest trees filter chronic wind-signals to acclimate to high winds. New Phytologist 210, 850-860.

Dalling JW and Turner BL (2021) Fortuna Forest Reserve, Panama: Interacting Effects of Climate and Soils on the Biota of a Wet Premontane Tropical Forest. Washington D.C., USA: Smithsonian Books, pp. 302.

de Langre E, Gutierrez A and Cossé J (2012) On the scaling of drag reduction by reconfiguration in plants. Comptes Rendus Mécanique 340, $35-40$.

Díaz IA, Sieving KE, Peña-Foxon ME, Larraín J and Armesto JJ (2010) Epiphyte diversity and biomass loads of canopy emergent trees in Chilean temperate rain forests: A neglected functional component. Forest Ecology and Management 259, 1490-1501.

Duryea M, Kampf E and Littell R (2007) Hurricanes and the urban forest: I. Effects on southeastern United States coastal plain tree species. Arboriculture \& Urban Forestry 33, 83-97.

Ennos AR (1991) The mechanics of anchorage in wheat Triticum aestivum L. 1. The anchorage of wheat seedlings. Journal of Experimental Botany 42, 1601-1606.

Flores-Palacios A (2016) Does structural parasitism by epiphytes exist? A case study between Tillandsia recurvata and Parkinsonia praecox. Plant Biology 18, 463-470.

Francisco-Ventura E, Menchaca-Garcia RA, Toledo-Aceves T and Kromer T (2018) Potential harvesting of fallen vascular epiphytes in a tropical montane cloud forest at Los Tuxtlas, Veracruz, Mexico. Revista mexicana de biodiversidad 89, 1263-1279.

Gómez González DC, Zotz G and Bader MY (2021) The role of epiphytes in rainfall interception of a tropical montane cloud forest in Panama. In Dalling JW and Turner BL (eds), Fortuna Forest Reserve, Panama: Interacting Effects of Climate and Soils on the Biota of a Wet Premontane Tropical Forest. Washington, D.C.: Smithsonian Books, pp. 203-212.

Hackenberg J, Morhart C, Sheppard J, Spiecker H and Disney M (2014) Highly accurate tree models derived from terrestrial laser scan data: a method description. Forests 5, 1069-1105.

Hackenberg J, Spiecker H, Calders K, Disney M and Raumonen P (2015) Simple tree-An efficient open source tool to build tree models from TLS clouds. Forests 6, 4245-4294.

Hale SE, Gardiner BA, Wellpott A, Nicoll BC and Achim A (2012) Wind loading of trees: influence of tree size and competition. European Journal of Forest Research 131, 203-217.

Hales WB (1949) Micrometeorology in the tropics. Bulletin of the American Meteorological Society 30, 124-137.

Harder DL, Speck O, Hurd CL and Speck T (2004) Reconfiguration as a prerequisite for survival in highly unstable flow-dominated habitats. Journal of Plant Growth Regulation 23, 98-107.

Harder DL, Stevens CL, Speck T and Hurd CL (2006) The role of blade buoyancy and reconfiguration in the mechanical adaptation of the southern bullkelp Durvillaea. In Herrel A, Speck T and Rowe NP (eds), Ecology and Biomechanics - A Mechanical Approach to the Ecology of Animals and Plants. Boca Raton, Fl, USA: CRC Press - Taylor \& Francis Group, pp. 61-84.

Hietz P (1997) Population dynamics of epiphytes in a Mexican humid montane forest. Journal of Ecology 85, 767-777.

Hietz P, Ausserer J and Schindler G (2002) Growth, maturation and survival of epiphytic bromeliads in a Mexican humid montane forest. Journal of Tropical Ecology 18, 177-191.

Hirsh H and Marler T (2002) Damage and recovery of Cycas micronesica after Typhoon Paka. Biotropica 34, 598-602.

Johansson D (1974) Ecology of vascular epiphytes in West African rain forest. Acta Phytogeographica Suecica 59, 1-136.

Latimer WM (1950) General meteorological principles. In National Defense Research Committee (ed.), Handbook on Aerosols. Washington D.C., USA: United States Atomic Energy Commission, pp. 15-39.
Laurance WF (2006) Fragments and fire: alarming synergisms among forest disturbance, local climate change, and burning in the Amazon. In Laurance WF and Peres CA (eds), Emerging Threats to Tropical Forests. Chicago, USA: University of Chicago Press, pp. 87-104.

Laurance WF and Curran TJ (2008) Impacts of wind disturbance on fragmented tropical forests: A review and synthesis. Austral Ecology 33, 399-408.

Lawton RO (1982) Wind stress and elfin stature in a montane forest tree: an adaptive explanation. American Journal of Botany 69, 101-116.

Lowman MD and Linneroth W (1995) Population dynamics of some native Florida epiphytes. II. Mortality after a storm. Journal of the Bromeliad Society 45, 15-17.

Lugo A, Applefield M, Pool D and McDonald R (1983) The impact of Hurricane David on forests of Dominica. Canadian Journal of Forest Research-Revue Canadienne De Recherche Forestiere 13, 201-211.

Matelson TJ, Nadkarni NM and Longino JT (1993) Longevity of fallen epiphytes in a neotropical montane forest. Ecology 74, 265-269.

Montaña C, Dirzo R and Flores A (1997) Structural parasitism of an epiphytic bromeliad upon Cercidium praecox in an intertropical semiarid ecosystem. Biotropica 29, 517-521.

Moore J, Gardiner B and Sellier D (2018) Tree mechanics and wind loading. In Geitmann A and Gril J (eds), Plant Biomechanics - From Structure to Function at Multiple Scales. Cham, Switzerland: Springer, pp. 79-106.

Niez B, Dlouha J, Gril J, Ruelle J, Toussaint E, Moulia B and Badel E (2020) Mechanical properties of "flexure wood": compressive stresses in living trees improve the mechanical resilience of wood and its resistance to damage. Annals of Forest Science 77, 17.

Nilsson C, Stjernquist I, Bärring L, Schlyter P, Jönsson AM and Samuelsson H (2004) Recorded storm damage in Swedish forests 1901-2000. Forest Ecology and Management 199, 165-173.

Paton S (2021) Monthly summary_Fortuna Station. The Smithsonian Institution, figshare data repository. Version 10, data posted: 26.02.2021. https://doi.org/10.25573/data.10059476.v10

Perez-Noyola FJ, Flores J, Yanez-Espinosa L, Jurado E, Gonzalez-Salvatierra C and Badano E (2020) Is ball moss (Tillandsia recurvata) a structural parasite of mesquite (Prosopis laevigata)? Anatomical and ecophysiological evidence. Trees 35, 135-144.

Pett-Ridge J and Silver WL (2002) Survival, growth, and ecosystem dynamics of displaced bromeliads in a montane tropical forest. Biotropica 34, 211-224.

Prada CM, Morris A, Andersen KM, Turner BL, Caballero P and Dalling JW (2017) Soils and rainfall drive landscape-scale changes in the diversity and functional composition of tree communities in premontane tropical forest. Journal of Vegetation Science 28, 859-870.

Raumonen P, Kaasalainen M, Åkerblom M, Kaasalainen S, Kaartinen H, Vastaranta M, Holopainen M, Disney M and Lewis P (2013) Fast automatic precision tree models from terrestrial laser scanner data. Remote Sensing $\mathbf{5}$, 491-520.

Rodríguez-Robles JA, Ackerman JD and Meléndez EJ (1990) Host distribution and hurricane damage to an orchid population at Toro Negro forest, Puerto Rico. Caribbean Journal of Science 26, 163-164.

Sarmento Cabral J, Petter G, Mendieta-Leiva G, Wagner K, Zotz G and Kreft H (2015) Branchfall as a demographic filter for epiphyte communities: Lessons from forest floor-based sampling. PLoS ONE 10, e0128019.

Schlichting H and Gersten K (2017) Boundary-Layer Theory, 9th Edn. Berlin, Heidelberg: Springer, pp. 814.

Schmit-Neuerburg VM (2002) Dynamics of vascular epiphyte vegetation in the Venezuelan lowland rain forest of the Surumoni Crane Project. $\mathrm{PhD}$ Dissertation. Rheinischen Friedrich-Wilhelms-Universität, Bonn, Germany, pp. 195.

Skutch AF (1930) On the development and morphology of the leaf of the banana (Musa sapientum L.). American Journal of Botany 17, 252-271.

Strong DR (1977) Epiphyte loads, tree falls, and perennial forest disruption: A mechanism for maintaining higher tree species richness in the tropics without animals. Journal of Biogeography 4, 215-218.

Tay JYL, Zotz G, Puczylowski J and Einzmann HJR (2021) Go with the flow: The extent of drag reduction as epiphytic bromeliads reorient in wind. PLoS ONE 16, e0252790.

Telewski FW and Pruyn ML (1998) Thigmomorphogenesis: a dose response to flexing in Ulmus americana seedlings. Tree Physiology 18, 65-68. 
Tremblay RL (2008) Ecological correlates and short-term effects of relocation of a rare epiphytic orchid after Hurricane Georges. Endangered Species Research 5, 83-90.

Vogel S (1984) Drag and flexibility in sessile organisms. American Zoologist 24, 37-44.

Vogel S (1989) Drag and reconfiguration of broad leaves in high winds. Journal of Experimental Botany 40, 941-948.

Vozmishcheva AS, Bondarchuk SN, Gromyko MN, Kislov DE, Pimenova EA, Salo MA and Korznikov KA (2019) Strong disturbance impact of tropical cyclone Lionrock (2016) on Korean pine-broadleaved forest in the Middle Sikhote-Alin Mountain Range, Russian far east. Forests 10, 1017.

Zotz G (1998) Demography of the epiphytic orchid, Dimerandra emarginata. Journal of Tropical Ecology 14, 725-741.

Zotz G (2016) Plants on plants - The biology of vascular epiphytes. Switzerland: Springer International Publishing, pp. 292.

Zotz G, Laube S and Schmidt G (2005) Long-term population dynamics of the epiphytic bromeliad, Werauhia sanguinolenta. Ecography 28, 806-814. 